International Journal of Traditional and Complementary Medicine
(ISSN:2474-1361)

\title{
Eve \& Evil. Hypnoanalysis of Demonic Possession. A Case-Study.
}

\section{József P. Vas MD}

H-+527. Soltész Nagy Kálmán u. 1. 1/5, Miskolc, Hungary.

\begin{abstract}
A woman, named Eve, has been possessed by Evil. She is ${ }^{*}$ Correspondence to Author: continouosly tortured by host of visions and cursed by demonic József Pál Vas voices. She has a miscarriage and commits suicide several times. The therapist builts up a Jungian type of hypnotherapy H-+527. Soltész Nagy Kálmán u. 1. and hypnoanalysis based upon Eve's fairy tale experiences come $1 / 5$, Miskolc, Hungary. from her childhood. The patient's absolute good and evil selfand object representations develop in a mutual relationship each other in the form of miscellaneous symbols. Finally, a prolonged How to cite this article: struggle of good and bad symbols arrives at a neutral point of rest. Since the therapist is not afraid of Eve's experiences he wants to take part in them, which leads to a mutual experience Józs ef P. Va. Eve \& Evi I Hypnoanalysis of Demonic Possession. A Case-Study. of tandem hypnosis shared by both the patient and the therapist. Facing together with Evil the therapist becomes as a devil in a symbolic way while the devil is made gentle as an uncle of Eve's life. Finally, the patient's psychosis is healed.
\end{abstract}

Keywords: demonic possession, hypnotherapy, hypnoanalysis, good and evil symbols, tandem hypnosis

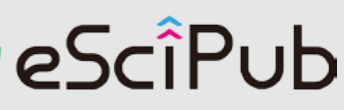

eSciPub LLC, Houston, TX USA.

Website: http://escipub.com/ 


\section{Exploration}

The date was 22. 02. 1989 when I was on duty at Dept. of Psychiatry in Borsod County Hospital, Miskolc, Hungary. At 2.00 a.m. an attractive woman was sent from Dept. of Toxicology because she attempted suicide with medicine and after toxic symptoms vanished a psychotic state was turned out. Her report was both fascinating and horrible as following:

"I wanted to commit suicide because I was kept on forcing to do so due to voices of somewhat spiritual creatures or space beings. They said that I was treated as a guilty person to be shot unless to poison myself. I must die since I'm a killer, l've killed a man. It happened the last summer that my husband and I were on weekend. A woman from next door invited me to pay a visit at her, and, we drank a glass of beer. After a while I began to feel a strong dizziness as if woods had come nearer to me. Now I think of being poisoned by her. I felt as if I was blown up but I had a vague recollection of it. I might have stripped to the skin and ran away towards to woods where I had sexual intercourse with three young men. Returning the neighbor's house I noticed a knife dripping with blood in my hand, and, I really didn't know if I had killed someone or not. I've another recollection to see a man with red beard and two horns on his head. He had hooves. He looked like a Centaur. He raped me. Then I fought against him and I knifed him but he rolled away laughing horribly and told me: "You killed yourself!» During the whole scene horrible shrieks, screams and giggles were heard. I saw a white figure with a rope in her hand, and she told me: "Don't you recognize me? I am you personally. You'll hang yourself with this rope!» Then I saw black devils all around me, who were pushing each other. Each of them declared himself to be good and the others to be evil. I got to know that they were space creatures, who observed people on Earth. They think of people to be stupid because people assume themselves to be the lords of the world but this isn't the case.
Conversely, the devils claimed themselves to be the lords of Universe. I have to die since I've learned their secret. They are invisible light creatures that live in pinecones. They've no body so they must borrow the bodies of dead men in order to become visible. Actually, I could see and hear some dead people I had known before. They were black. Only my alterego was white as she was still alive. They predicted to me the date of my miscarriage, and, it came true. The date was also predicted when I would attempt suicide and it really happened, too. I've attempted suicide three times up to now. Then I can remember that my neighbor made me drunk on rum, and, she laid me on the bed, and, she became a hermaphrodite and raped me. Then I must have fallen into a deep sleep. Next day I couldn't remember anything, but a day later I dreamt it all again. From that time on I began to hear the voices of those space creatures and their evil prophecies about my death and my family's misfortune."

It was a horrible experience for me as a therapist to listen to the patient. Her big black eyes enchanted me as if coming form a Mayan priestess' magic, while her face of Mongolian features called to mind a Siberian Shaman world. She reminded me of a fortuneteller, too, and I shivered with an idea that she would tell my fortune. I felt attraction and repulsion at the same time. Clearly, her case was not of a classic possession, in which a wicked demon seems to possess body and soul; her experiences reminded me much rather of Dionysian bacchanalia or witch-Sabbath.

\section{Anamnesis}

Eve is a 34-year-old woman married two years without children. Her pregnancy proved to be endangered because of Rh incompatibility, and, she aborted at the time it was predicted by space creatures in her hallucinations. She could not explain why she didn't get treatment for her Rh incompatibility. Her mother confined her independency during childhood. When she moved into a new house after her marriage, the mother said »lt is as if you had died «. The 
maternal grandmother lived with them since that time when her son, who was Eve's uncle, had been prisoned because he knived his love partner due to his jealosy. This seems an important fact because Eve also knived a devil in her fantasy. Due to sorrow her grandmother became psychotic, and, she was possessed by magic force with riding on broom, stopped cars and fortold to people. As it turned out, this grandmother was treated at Dept. of Psychiatry by me in 1971. In her adolescence Eve heard from that "witch grandmother", that the devil was able to steal into girls' genitals and she believed it. Eve thought of herself being as ugly as the devil and she would have liked to tear her skin away. She got married rather late because of failures in her previous partnerships.

\section{Spiritual backround}

Eve, the patient had been striken by a curious possession that seemed to be closely related to conception and the female gender role. It is likely to be a counterpoint of immaculate conception equal to Evil possession to incarnate as a new life relating to Eve' destiny. It can be named as "Conceptio Maculata" in Latin or "Maculate Conception”, begetting guilty concepts leading to possession psychosis. This type of possession may be considered to be the most intensively experienced knowledge of primordial sin, yet a self-awareness of Evil, an „under-human” knowledge, and, a transcendent, high-ordered experience to fulfill divine judgement at the same time, which proved to be unbearable like Eve' pregnancy.

From an ancient legend Carl Gustav Jung cites that primordial Evil is likely to be Lilith a snake of Paradise, who was Adam' first wife. She seduced Eve to eat the apple (Jung, 1973a \& 1993). In this way Satan puts a spell on Eve, whose first-begotten son the fratricide Cain carries Satan's portrait (Szondi, 1987). Eve and Adam ate the apple from the tree of knowledge, that both made them learn matters of life and possessed by Evil. This was the reason why they had been chased out of Paradise. May we say that this event was the first exorcism. Jahve usually chases out Evil from Satan's victims, as Jung points out, however, Satan is merely viewed as a naughty jester according to Jahve till Christ appears on the scene. The Blessed Virgin's Immaculate Conception by Holy Spirit is equal to a "blessed possession". Her Son is Jesus, whose mission is to undertake to bear the sins of world. As a matter of fact, the sins of world are viewed as a consequence of people's moral fault caused by Evil possession. The Devil prefers to sleep with women in Christian myths. Merlin, the Celtic magician was born in such a way, supposedly (Vámosi-Nagy, 1985). Men can also be possessed by Satan as we can see in the cases of Knights of the Temple, Faust, and Don Juan. However, demonic possession of a woman, more importantly still a woman's body seems more important than the previously mentioned possession of men since it fills her with such sateless desire in her reproductive organs as to push her to Satan according to the viewpoint of Middle Ages (Friedenthal, 1978). Since creation of male principle seems as the primary task, thus woman is treated as an inferior copy of man, merely a castrated imitation, due to infernal forces gaining access and manipulating the process of creation (Safranski, 1997). We should not forget that the satanic features of seduction and being seduced are always, and at all times are associated with Eve, the eternal woman (Young-Eisendrath \& Wiedemann, 1987).

Since womanhood bearing the original sin, from the Middle Ages, culture has tended to restrict female destiny into extreme role possibilities as evil or angel as can be read in Goethe's Faust. Identifying with projections of dominant sex women become to be embodied to be either divine beauty, goodness, and virtue even prudence (see: divine Sophia) or infernity, sensuality, wickedness, and monstrosity (Jung, 1973b; Pisztora \& Kunt, 1980). These extrems are luckily equalized by an exalted motherideal in the worship of Mary, The Blessed Virgin, which can alleviate splitting to good and bad features of womanhood. In European 
cultures analogous characters are also found as symbolic figures of charity and wickedness like the Fairy Helen ${ }^{1}$.

\section{Sociocultural backround}

Crossing over from the spiritual dimension of human existence to the society, possession is interpreted by some authors as a learned interpersonal role of either exalting or condemning bias of the community. Individuals, who have low social status, tend to take this role. To exhibit their otherness in this way they can enjoy both a certain esteem and respect mixed with fear inside their community. Bourguignon (cit. Pattison, Kahan \& Hurd, 1986) considers to be the social conditions of demonic possession: 1 . existence of an oppressive social structure; 2 . loss of faith in the effective functioning of civil organizations; 3 . hopelessness of the fight against the wickedness of the system of social institutes. The factors mentioned above lead to social conflict, in which demonic possession personifies the social evil since there is no other possibility for protest against oppression (Schram, 1982).

In archaic cultures possession may be a part of such tribal ceremony, which serves survival of community (Hart, 1983; Krippner, 1993). Wolfgang Jilek (1988) describes a rite of passage named "Spirit Dancing” of Salish Indians, who locates along the Canadian coast of Pacific Ocean. This rite serves to mobilize Indians' hidden sources of energy by means of inducing trance state as their vitamin reserves has been run short at the end of winter.

\section{Nosology}

In psychiatric nosology possession is treated as a form of manifestation of culture-bond reactive syndromes. This syndrome is often characterized by stereotyped behavior of psychotic degree without can be classified into the list of such great psychopathological entities as schizoprenia, bipolar affective disorders, etc. It is used to consider to be hysteric disorder as

\footnotetext{
${ }^{1}$ Fairy Helen (Tündér Ilona in Hungarian) is seemed as an
} important figure of charity in Hungarian folktales.

IJTCM: http://escipub.com/international-journal-of-traditional-and-complementary-medicine/ having a tendency for dissociation, although there is no sign of previous development of personality characteristic to hysterics. Possession topics can be involved in such disorders as schizophrenia, cyclophrenia, and paranoid psychoses, nevertheless, it is seen to be originated from culture as a pathoplastic effect in these cases (Pattison, Kahan \& Hurd, 1986).

A special form of dissociation seems to be effective in psychotic possession state. In this form two „persons”, an ego-identical and an ego-alien, struggle for having control of the patient's mind. These sub-persons are not bordered by amnestic barrier in contrast to multiple personality disorders (Watkins \& Watkins, 1986). This definition is suitable to peripheric possession to exhibit strikingly pathologic features. On the contrary, other individuals can experience central possession for a definitive period under the supervision of conscious control of will. It can happen in the interest for ritual aims while signaling a certain position inside a community to be accord with its religious traditions and moral values without having an ego-alien feature. This central type of possession could not be identified as a definitive mental disorder. As an example we can see the prophets' social role (Spanos, 1989).

\section{Diagnose}

It was an uncommon fact that data of Eve' life story had hardly be gained so the whole narrative of her life would be completed at the end of therapy only. Whether she could not or did not want to speak of her experiences or could not remember early life events, I really do not know. It seemed as if her inner world had been splitted into a real and a psychotic part; I was told her agonizing fantasies while remaining silent about past, nevertheless, she did not tell psychotic symptoms to her parents. Her consciousness became completely filled in with psychotic anxiety and pessimistic delusions assisted with secundary hallucinations and illusions. Often she was just 
sitting in a corner all day long while kept on thinking about how to kill herself.

The diagnose was Demonic Possession (Ward, 1989). Her psychotic experiences comes from shadow as a part of Jungian collective unconsciousness (Jung, 1978). Figures of her visions equal to archetypes of collective unconsciousness. A devil with hornes and horseshoes is a well-known symbol representing Evil since Byzantine Christianity while a Centaur indicates an analogy of devil according to both pagan world and early Christianity (Jung, 1993). In addition to bisexuality a hermaphrodite means symbols of either abiogenesis or creation of world. A mythical relationship between spiritual creatures and abortion is depicted in a Mordvinian $^{2}$ myth of creation. There is a goddess named Ange-Patäi, whose company consists of unborn babies' souls. In accordance with Eskimos' faith dead' soul live in a pinecone ${ }^{3}$, which can be seen only by a magician, who is able to breathe life to sick people (Szimonidész, 1931). The spirits announced that they were only visible by mental, alcoholic and drug patients as Eve told me later.

Universal laws in force are likely to be reflected in Eve' possession state: cultural inheritence of mankind endeavours to surface in the form of archetypes from conception of culture to its end threatened with destruction, until apocalypse. From standpoint of apocalypse seems to be indifferent event either if a vision of a descending woman from the heaven, whose baby just coming to life is looked out for a bloodthirsty dragon according to Book of Revelation are embodied in Eve' visions or flying objects appear on the scene. We can feel a typical sense of fin de siécle in 20. century when first resonances of a cosmic catastrophe may become stronger in an extremely sensitive individual.

\footnotetext{
2 Mordvinian people locate in Ural-Altaic region of Asia.

3 Eve was told this by space creatures.
} IJTCM: http://escipub.com/international-journal-of-traditional-and-complementary-medicine/

\section{Therapy}

One can raise a question whether somewhat therapy could be for healing Eve'anguish (Berwick \& Dougles, 1977; Gabbard, 1994). Whether Eve' experiences are needed to be corrected at all. Is it necessary, could it be possible to be changed? May it be named as psychotherapy that I want to do? I decided to help her, and I would find answers to my questions and doubts later. She got a massive antipsychotic drug treatment, meanwhile four months passed without any success. Her anxiety states, suicidal drives and subject of possession remained as unchanged. I was thinking more and more of her healing as an impossible task for me, and, even her loss. The therapy came to a deadlock.

By that time I finished individual psychotherapy of a schizophrenic patient, and I had enough capacity and ambition to start Eve' psychotherapy. When my plan was told she responded almost with pleasure. A guiding principle of my hypnoanalytic project was both stopping her split-off self-image and processing of her evil self-representation projected into psychotic delusions (Brown \& Fromm, 1986; Hilgard, 1986). Traumatic shock in which procession of outer informations became interrupted can be interpreted as a deep pathological trance according to Ferenczi's theory of trauma (Ferenczi, 1933/1992). In order that trauma be processed the unconscious core of ego aimes at producing of a similar state even if psychosis be broken out, which can be suitable to a pathological form of trance (Edelstein, 1981; Levin, 1996). As a result spirit can get away from the bottle so there is needed to have a spell for commanding back. When a mild trance state is produced due to hypnosis in the frame of therapy the split-off parts of ego might become fused again via this induced state.

Some representatives of psyhoanalytic literature treat hypnosis to be mild trauma to induce trance making traumatic experiences possible for processing (Merkur, 1984). 
Literature of dissociation mentions a theory that specific sensitivity for trauma depends on an effect of trauma to induce trance. What does not cause trance state that does not cause trauma since ego boundaries will not be penetrated (Herman, 2003; Watkins \& Watkins, 1986).

An intensive individual therapy started in summer of 1989 continued for 12 months including 58 sessions. As she used to love reading Fairy Helen tales to her two younger sisters in the childhood I asked her to imagine to be in Fairyland. She has got a high susceptibility so it was easy for her to get into hypnosis, and her imaginations were freely flowing (Bettelheim, 1976; Gill \& Brenman, 1959; Weitzenhoffer \& Hilgard, 1959; Sarbin \& Coe, 1972). I started every new hypnotic session with a recall of her previous imagination. It served to apply a special technique of induction, to maintain her motivation for continuing therapy, and, to mobilize imaginative involvement (Hilgard, 1974 \& 1979). As a consequence a serial tale-novel was produced by the authors, who were Eve and me.

\section{The pre-Oedipal phase of therapy}

During the first hypnosis she starts form reality to fantasy. At the end of a village she can see a mother dog with seven puppies. She follows them to a dense forest when she quickly notices Fairy Helen in her long white dress, and golden hair. The Fairy feeds the hungry dogs then flying from tree to tree ${ }^{4}$ she is leading Eve to a beautiful fairy castle. Eve wants to be invisible even for Fairy Helen because of her fear for everyone. Fairy Helen's life consists of doing good things e.g. feeding animals, helping people, and, she does not need anybody to live together with. Fairy Helen equals to Eve' splitted unconscious self-image, which has been exaggerated to be omnipotent so Eve has no a conscious knowledge of it (Kohut, 1977).
The second imagination is recorded as an original dialogue with my comments written later.

Eve (E): The Fairy Castle's turning round and round on a duck's foot.

Comment: It is characteristic of Hungarian folktales. But to tell the truth there was a strange clickling noise coming from my cassette recorder during the whole recording time.

$\mathrm{E}$ : There're gilt palettes on the windows. The Castle's turning round and round, and, soft music's sounding from the inside. The bedroom's covered with golden brokade. There's a sweet tiny place where the fairy girl's sleeping, a nice fourposter bed. Everything's beautiful. The fairy's got golden slippers. But she's anxious.

Therapist $(T)$ : Why's she anxious?

$\mathrm{E}$ : Because of a wicked witch. She was threatened with destruction by that wicked wich if she continued to help people and animals.

$\mathrm{T}$ : The fairy must have a good idea how to defend herself.

E: Yes, surely. But her magic power's less than the witch's. The fairy's able to transform herself into every kind of animals or plants....and the wicked witch's coming...

$\mathrm{T}$ : What does the wicked witch look like?

$\mathrm{E}$ : She is an ugly iron-nosed witch, toothless, with pimply nose, covered with black dress, a lot of hair's swinging on her face, she's got huge grotesque nails. And she is coming on her witch-broom.

Comment: It is my luck that my name is Vas (Iron in English) so a special part-object transference can be easily established by the patient with me (Fromm, 1984; Kernberg, 1985).

T: I can't think of witch to have a goal to destroy the fairy as she fights against nobody. She might simply want to threaten the fairy, I mean.

\section{E: Indeed.}

\footnotetext{
${ }^{4}$ It is analogous to Siegfried's first Rhine's journey when the 
T: Should you scrutinize the wicked witch...She must have some weakness...You may find it out.

E (after some time): The iron-nosed wicked witch's power's in her nose. If this nose were cut off with a knife her magic power would be lost...But the fairy doesn't want the witch be destroyed because of her goodness.

Comment: According to her fantasy Eve daggered a devil with the knife in her psychotic state. It seems as if she does not want to do so again. At the same time we can remember in her life story when her grandmother's behavior was similar to a wicked witch.

T: What's happening now?

$\mathrm{E}$ : The witch's just flying towards the castle. The fairy's having her breakfast at home.

$\mathrm{T}$ (hesitatingly): They might sit down to have a negotiation.

E: No. The witch's screeching: "l've said that you'd be destroyed if you helped people and animals!« The fairy's got frightened so much at this screeching that she's transformed into a fawn.

$\mathrm{T}$ : I see.

E (excitedly): The wicked witch's starting to pursue her, the fawn's running, running and running, with the witch on her broom sweeping after her. The fawn's almost been caught.

T: The witch isn't at home so she isn't in a place of safety.

$\mathrm{E}$ : She isn't, she isn't.

T: Someting wrong would happen to the witch.

E: Now the fairy's been transformed into two apples from the fawn. The apples've been picked up by the witch but they're rolling away out of her hands, she isn't able to grasp them, they're rolling and rolling downhill, rolling and rolling. She's running after them but she isn't able to grasp them at all.

$\mathrm{T}$ : The witch must be very angry.

$\mathrm{E}$ : Indeed... The witch has almost grasped them. Now the fairy's transformed herself into a rabbit. She starts running. She's running downhill to a dense forest. The witch isn't capable to follow her...The fairy's running out of he forest in the figure of a rabbit. She's been transformed into a dog....She attacks the witch. She bites the witch in the leg. The witch's screaming, she gives up struggling and goes home to cure her hurts...The fairy's transformed into her original beauty and also goes home...She puts on her dress and goes to the mother dog and her puppies in order to feed them. The puppies're hungry. She gives them delicious foods of all sorts. They're satisfied very much with their milk.....Now the witch starts to battle again. The fairy's transformed into a dog and she cuts the witch's dress into strips.

T: Why do you think the witch to be so wicked?

E: Because she has got an ugly figure, ${ }^{5}$ and, since she can't be so beautiful as the fairy is so she wants to destroy the fairy... The dog's still cutting the witch's dress into strips. The witch hits the dog with her broom, it begins to scream and is transformed into a fawn again, who starts running and running and running because the witch begins to pursue her, again.

$\mathrm{T}$ : That witch must have a misfortune, therefore she may dislike the fairy.

$\mathrm{E}$ : Maybe. The fairy wants to help the witch to be good. She wants to talk with her but the witch doesn't want to do so.

T: What're they talking about?

$\mathrm{E}$ : The fairy asks the witch not to be so wicked but the witch begins to drive the fairy again. The fairy begins to run but her dress gets caught in a branchlet and the witch grasps her hand then twists it...Oh! It hurts, it hurts! ${ }^{6}$... Suddenly the fairy snatches away her hand from the witch,

\footnotetext{
${ }^{5}$ We can remember that Eve thought of herself to be ugly in her adolescence.

${ }^{6}$ Eve cryed loudly because of having pain.
} IJTCM: http://escipub.com/international-journal-of-traditional-and-complementary-medicine/ 
and, she's transformed into a fawn again and starts running...The fairy comes a decision to kill the witch. But she mustn't kill anyone.

T: She shouldn't kill the witch if she knew how the witch's evil could be neutralized.

E: She's got her power in her nose...The fairy's to be transformed into a strong young man in order to cut the witch's iron-nose off. She's transformed into a heroic young man, who grisps his sword and is flourishing it towards the witch beside her, to the right, to the left ${ }^{7}$, threatening her....The witch looks very frightened...finally the young man manages to cut her nose off...The witch begins to be transformed into a charm old lady.... white-haired doddering old woman, who has never been wicked.

$\mathrm{T}$ : What will the old woman do?

E: She'll be so good as Fairy Helen. She will help people and animals.

The iron-nosed witch proved to be a repressed, totally bad part of Eve' self-image. What does the witch symbolize? The witch is obviously her grandmother, and its effect to Eve' egodevelopment in the form of a symbol. To be cut off the witch's nose with the knife can be interpreted as a compound symbolic act. Firstly, her grandmother's personality characterized by phallic aspect, and its effect exerted on Eve; secondly, her uncle's attempted murder, a traumatic event, which caused guilt to the whole family for generations.

May it be possible that space creatures in Eve' hallucinations predict destruction of members of the family for the previously mentioned reason? So their prophecy can be comprehended as an apotheosis of family curse. Heroes of Greek Tragedies suffer this way for the sake of ancestors' sins. I was pondering about the problem how transformation of traumatic events happened in trance state. While Eve was in the captivity of deadly fear, the symbol of omnipotent goodness and beauty Fairy Helen

\footnotetext{
${ }^{7}$ It is as if the young man could give blessings.
}

IJTCM: http://escipub.com/international-journal-of-traditional-and-complementary-medicine/ 
In the course of a waking conversation Eve is asked to associate to her experience of hypnosis. In this way some more traumatic memories could be explored in addition to those that have already been recognized. Eve says that her father became seriously ill when she was 14. He suffered from cancer of the stomach, and, underwent an operation. That time on she was always thinking of his death, despite of the fact that her father totally recovered. She feared of cancer very much. She was imagining her cancer involving her breast and genitals. She believed that she would never allow herself to be pregnant and to suckle a baby if she would have a cancer. Now she realizes that she began to hear the voices of space creatures only after her miscarriage. She became anxious when informed about her Rh incompatibility and therefore she considered herself as evil. Up to now she has not ever been able to speak about the experience of her abortion. It was so horrible! She saw a 18week-old fetus having all parts of its body evolved, and, she thought about if this human being had already had a soul or not. She took herself for assassin since her fetus was "killed” by her. I make a remark that the voices also took her assassin to be punished. I tell her about some comparisons that can be seen between her father' cancer and its operation, and her fear of cancer, and her pregnancy, which had a bad outcome. ${ }^{8}$

The injured animals in the third hypnosis, and the injured people with abdomens having been cut in the fourth hypnosis can be considered as representatives of trauma especially of genital trauma as in the case of abortion. Eve' notion about if her fetus had got a soul or not is analogous to what is pictured in the fourth imagination i.e. children' and people' souls gone through the hole of their abdomen. It is now understood why her psychotic content upon space creatures has been evolved. Eve were told about these creatures having no

\footnotetext{
${ }^{8}$ Moreover, an embrio's development means a controlled cell
} division but a cancer means cell division out of control.

IJTCM: http://escipub.com/international-journal-of-traditional-and-complementary-medicine/ bodies during her hallucinations. So they are identical with those, who flew from people' abdomen had been cut during hypnotic imagination. Thus their appearance was analogous to the fetus' death.

When Eve was talking about the forth imagination she did not mention the old lady. I asked her if the lady was present and Eve answered she was not. The old lady seems to represent Eve' disguised evil part further on, and, may be presented as the seven-headed dragon. After the therapy has finished I am thinking about her feelings relating to female sex and reproductive role as dangerous and bad for her. It was a part of her unsatisfactory feelings considering as her female appearance. Being poisoned was her unconscious fantasy about either alcohol abuse because she believed that her neighbor put poison into her glass of bear or her father was told that alcohol abuse had caused his cancer of the stomach. Moreover, incurable $\mathrm{Rh}$ incompatibility „poisoned” her fetus. As a matter of fact, her suicide attempts and poisoning the dragon as a symbolic figure of mother can be considered as analogous event and experience. So Evil is embodied for Eve as female and maternal roles for her bad self-parts to be destroyed (Freud, 1905/1953; Laufer, 1991).

The neglected and repressed evil part of Eve' Ego, that is, her feminism, became projected into psychotic world as a devil, a Centaur, and a hermaphodite. In the beginning of psychosis possession theme belongs to Id functioning. After abortion her sadistic Superego functioning became dominated as voices, which made her commit suicide since she felt guilt (Masterson \& Rinsley, 1975). For the purpose that her evil part be counterbalanced the representative of all-good and omnipotent Superego part was presented as Fairy Helen, who was capable to win over the witch and the dragon in the course of imaginations.

In the next hypnotic imagination Eve notices twelve doors in the castle. She askes Fairy Helen to open the first door. It is an important 
thing to communicate to her good self-part. She can see bloodthirsty lions. She feeds them according to my suggestion. It is the first contact with evil part of her self. Behind the next door Eve looks at gamblers and murderers. They have been imprisoned by the Fairy. Eve is astonished at her strictness.

So far every hypnotic session has finished with a result for bad figures to be good, who, finally leave the scene so her imaginative field has become empty. It is a question why she wanted everybody to be good at all. Rüdiger Safranski mentions (Safranski, 1997) that Evil may be treated as a drama of freedom, which begins with Adam and Eve, who have become chased out of Paradise.

\section{The Oedipal phase of therapy}

Leaving the second room of the castle Eve is taking delight in the sight of furniture, especially, of a chair. She asks Fairy Helen to give her this chair as a present but the Fairy refuses to do so because it is said to be a magic chair she has inherited from her father, who was a famous sorcerer. The chair is used by the Fairy to make evil people become good. Eve asks the Fairy to let her sit on the magic chair. After sitting on the magic chair Eve is capable of flying to her joyful surprise. She is flying out of the window of the castle above the peaks of pinewoods to clouds and back. To the end of their trip she has been tired very much. In the moment I make a technical mistake to forget to withdraw suggestion of her capability to fly. Naturally, her flying ability has stemmed from her own suggestion to be my excuse. This imagination will be of a curious consequence. After the next weekend she talks about a bicycletour with her husband. In a sharp bend she exactly has flown down from the bicycle and hurt on her face. My interpretation is that she needed in reality to try her ability to fly. So not the space creatures' prophecy but mine has become true. She has a good laugh at that. Despite of the accident with the bicycle being akin to a symbolic suicide act, her "flying imagination" could be a turning point in Eve' psychotherapy. First, she identified herself with her bad self-part while sitting on the magic chair, which serves to repair evil people. Second, the magic chair as an inheritence of magician father is a symbol of hypnotic relationship, that is, a copy in fantasy of the real chair, in which she sits and "fly" into hypnosis in my room. Her "flying" seems as the first sign of establishing positive transference; by virtue of the therapist's magic power she can fly. This suggestion replaces evil prophecies of the space creatures.

During the 6th hypnosis Eve enters the next room when she can find a lot of nice dresses and jewels. She wonders why Fairy Helen gives her some of them since she has not worked for them. She puts a nice dress and a collar of pearls on, then, looking at herself in the mirror she finds herself to be prettier than before. Then she opens the door of the next room and she notices two bloodthirsty dogs keeping eye on a well. Eve realizes that there is water of life in the well that serves to maintain immortality of fairies by drinking from it. So she must not drink of it. I propose that she should wash her hands and face in order to have a long life and luck. Finally, she is having a bath in the water of life then puts her new dress and shoes on. After hypnosis she feels better as if some weight has left her chest and she looks at me with a soft glance for the first time.

It is curious that the theme of the 7th hypnotic session avoids fairyland and deals with more realistic events as if she wants to repeat the bicycletour she has taken before. A man with a straw-hat carries her by bicycle through the countryside, where she is travelled earlier. It is a hot summer noon, she wears bathing dress, which sometimes tends to slip down. The man buys ice-cream to her.

The fairy castle emerges again during the 8th imagination. I suggest that she should meet something akin to that of experienced in her hallucinatory state. Afterwards, entering the next room she can find a giant tied down. Fairy Helen punished him for his aggressive actions 
as destroying people's villages and towns. Eve asks the fairy to let him go away and the hall becomes empty. Then, in the next room Eve can see a lot of dwarfs pinching and annoying people. Some of them as "space-dwarfs” tell people evil prophecies. Fairy Helen has having them sit on the magic chair and the dwarfs are getting better while becoming quiet in a strange way. This hall also becomes empty. At that moment the man with the straw-hat emerges wearing a suit this time. He is Fairy Helen's servant. They start to furnish the two empty rooms for the Fairy and the old lady. Eve gives an order that the man will sleep in her fourposter bed. ${ }^{9}$ I as a therapist feel that her real needs and urges move in the empty rooms.

The 9th hypnotic session begins with a mythical picture: Eve finds a horse with wings behind the 7th door. Pegasus is also Fairy Helen's servant, who fulfills all of the Fairy's requests. Eve is making friends with Pegasus, who is taking a flight with her on his back. They are flying above wonderful lands, finally, touch down on the top of a high mountain in order to joy in the sight. On the way back Pegasus takes Eve down in a valley where raspberry bushes and some fruit trees can be seen. Eve is nibbling at the fruits. The man with straw-hat is coming to help Eve to get back the castle.

To sum up the latter four hypnotic sessions it can be assumed that a positive transference has been gradually evolved, which is depicted by means of some objects and events as the magic chair, Eve' capacity to fly, nice dresses and jewels Eve got presents, bathing in the well containing the water of life, flight on the back of Pegasus, and, finally, the therapist's representative figure ${ }^{10}$ as the man with strawhat. It is very important that not only her aggressive and fearful feelings but Eve' sexual wishes are also expressed as well in the symbols of hypnotic imagery. Moreover, positive transference has also been present in our "waking relations” due to her soft glance

\footnotetext{
${ }^{9}$ It is interesting that this bed was of the Fairy's one earlier.

${ }^{10}$ Naturally, he can also be the representative of her husband.
} IJTCM: http://escipub.com/international-journal-of looking at me with. It is useful to follow closely how the Centaur has gradually become tranformed via diverse metamorphoses from leaving Eve'psychotic vision's scene. The Centaur means as a symbol either irrepressibly brutal force or wish or cruelry or guilt and guilty people or wisdom. It is a double being: both infernal and celestial. The hermaphrodite devil can be seen as a primordial being to have double sexual identity at the beginning of Eve' psychosis, however, male and female sexuality are manifested in several figures in the world of hypnotic imaginations. Representatives of female sexuality are Fairy Helen, the witch, the fawn, the rabbit, the two apples, the old woman, the seven-headed dragon, and the blond woman, who poisons the dragon. The fawn, the rabbit and the two apples seem as the Fairy's alteregos she changes herself in the course of fight against the witch (Antalfai, 1999 \& 2006). There are the representatives of male sexuality, too: the bloodthirsty lions, the young hero, who "castrated" the witch's nose, the dogs two times, first as Fairy Helen's alterego, who cuts the witch's dress into strips, later the dogs keep on eye the water of life as two Cerberuses, the murderers and gamblers, the giant and the dwarfs, the magic power of the chair, a man with straw-hat, and, finally, the magic steed, namely Pegasus. On the magic steed Eve sits similarly as she sits in the magic chair and on the bicycle behind the man with straw-hat. The common ancestor of these miscellanous beings proves as the hermaphrodite devil comitted sexual aggression. This fact evidently demonstrates a purification process of sexuality with infernal $\sin$ in the course of the therapy (von Franz, 1992). Imaginative representatives of the previously mentioned monsters and wild animals can be considered as her distorted and projected sexual urges, which relates to a preOedipal phase of the therapy. It is also an important issue that after the monsters and wild animals there are depicted those imagery symbols of Eve' true wishes in consonance with reality as dresses, jewels, and the man with straw-hat. So Eve has already not been -of-traditional-and-complementary-medicine/ 
persecuted by her sexual and aggressive drives as mythical monsters, moreover, she gives me a soft glance as a present for the first time.

This period seems to have also been a crucial point of the therapy. The first man as a figure emerges in hypnosis relating to Oedipal-sexual paradigm of personality development. Unresolving mother-child pre-Oedipal conflicts has delayed to process Oedipal themes. For example her father left family for the sake of a woman when she was 18, and, she answered with a little girl's grief as she believed that the father left not his wife, but her as he did not love her. She talks about that event in the course of the therapy for the first time. She splits her sexual urges off. She has a dream about me appearing in a suit like the man with straw-hat. After being awaken she is preoccupying with a thought of killing herself all the day.

At that time I could not understand her intensive transference feelings. Partly, I think of her inner battle between good and evil self-parts, partly, I begin to give up hope that she can be completely cured again, because of her exaggerated suicidal drives. It is my countertransference reaction in which I have been projectively indentified with her bad prophecies (Ogden, 1982 \& 1986). I went on holiday before Christmas. I was tortured by misgivings. I was nearly sure of her committing suicide so I began my work a day earlier than it was planned, and, I arranged to be on night duty either. Everything happened by my "evil prophecy": at 6 p.m. she was brought in the Toxicology ambulance because of intoxication with medicine she had taken. We met in the common corridor of the two departments, Toxicology and Psychiatry. Luckily, her poisoning did not prove to be serious and she was sent to Dept. of Psychiatry soon. This suicide is akin to a reaction to anticipating abandonment.

During the 10th hypnotic session Eve enters the next room of the castle, and she finds herself in a stalactite cave. The scene is dreadful but she is brave to observe unexplored area. In a huge cave she notices a man playing the organ alone without any audience. She makes the man put the organ into an other cave crowded by people becoming fascinated to hear him play. Playing the organ (see: organism, even orgasm!) alone in a stalactite cave - I have never heard such an expressive symbol in connection with hypnotic relationship. The therapist as an orgonist keeping rules of therapy plays on Eve' emotions first, in a private situation in the frame of individual therapy, then, in front of large audience. This time Eve gave a written consent of her case to be published for educative and scientific goals.

Then an unexpected incident happens: her sister is sent to Dept. of Psychiatry because of psychotic state. She believed to her husband to have been possessed by devil, and she considered herself to be a healer person, who must drive out it from him. Eve is frightened of this fact, nevertheless, she does her best nursing her sister since they are in the same ward. Eve tells me her dream in which she has stolen my jacket, and, I have smoken a cigarette because of my anger. She knows that I hate smoking but she likes it. By that time I can realize her positive transference (Friedman \& Lavander, 1997).

\section{Tandem trance with the therapist}

The pre- and posthypnotic conversations and the 11th hypnotic session are demonstrated by the original dialogues and successive comments as following:

$\mathrm{T}$ : What about your anxious feelings?

$E$ : Well, they do exist. I'm always thinking of being killed. It's said by one of those creatures. There were different creatures: good and evil ones. They were pushing each other: «Now you can speak. But you can't speak this time! Don't believe him since he's evil, believe me instead!« It's so terrible! I've lost my mental balance since then, and, perhaps, I can't live a well-balanced life 
anymore. Those evil prophecies always rush into my mind because they've come true.

T: How do you think an outsider like me can help you?

Comment: This is the basic question. Actually, what can I do for her?

E: If I'm allowed to talk to you about that I feel relaxed. You know I can't speak to my neighbor or other people about that because l'd be said to be abnormal. It can't be regarded as a normal thing to have such hallucinations as I've had.

T: You know l've thought several times what I would have done if I had met those creatures or what I would do if I met them.

Comment: It is my first step to go into a deep common empathic trance.

E: After the event I think that I ought to have asked them something. Instead I felt deadly fear because the dead appeared on the scene in front of me. They said that they could see everything but they were invisible. The're visible only for alcoholics, drogabusers and psychotics. I myself could see them, too. One of them appeared to be an ordinary devil with a rope in his hand and was standing above me. He showed me the rope presenting my fatal end that l'd be hanged or committed suicide. He also said that I would poison myself several times. It has already happened four times. Could I struggle against their suggestions? It's all in vain. I always do what they say. I really don't know if I suggest myself or actually, they've the knowledge forward what l'm going to do. I'm in doubt if those creatures exist or not. It can't be conceived in a normal mind because you could say that there're no such things as space creatures. If they've an existence why they don't become visible for others, too? Why only for the drunkers, narcomanics and abnormal people?

T (after a long silence while hesitating): I've an idea, actually, what would happen....if once I met those creatures...could you imagine my meeting with them? What do you think about this appointment?

$\mathrm{E}$ (to my greatest surprise she laughs at me): Why, if you don't have a necrophobia?!

T (laughing in trouble): I don't think so.

Comment: Fantastic thing has happened: she has become relaxed and her anxiety vanished. If I am ready to meet those creatures existing in her fantasy, it means that (1) I can verify validity of her experiences, (2) from that time on she could not be regarded as a mental patient at all since a healthy person could experience as the same as she does.

E: Then, I think you'd dare ask them who they're, why they hide themselves if they exist.

T: Sure.

$\mathrm{T}$ : And what would you think they answer?

E: I've no idea about it.

$T$ (after a long while): What would happen if all of us met them now? You could imagine me being there, and, then, those creatures would come...And, something always happen. It's a simple imagination after all.

$\mathrm{E}$ (with a polite smile): Really?

Comment: Looking at the video recording it's exciting that situation reminds me of a courting scene as if I wanted her to be accept my emotional approaching or my seduction.

T (laughingly): And I do hope we will be alive after and we shall be sitting in this room having good humor. It could be an exciting adventure.

E (also laughing): Why, really, yes. It may be imagined that they would be meeting two of us, however, l've never met them before hypnosis...Are we going to try it?

Comment: Her tone is full of surprising excitement. She seemingly replaces the 
leading position from me urging the start of this „Magical Mystery Tour". ${ }^{11}$

$\mathrm{T}$ : Let's try it! There isn't going to be any trouble.

E: Why...I hope so (she's laughing). Then, can we start it?

$\mathrm{T}$ : All right. Let's start it.

Comment: The following scene is of an hypnotic induction with arm levitation as a deepening technique.

$\mathrm{T}$ : Look at the point on your hand and you'll feel soon to be put into hypnosis in much easier way than before. It'll be easy. There won't be anything burdening. It'll be just like when playing. Just like an interesting and exciting play. Just like when a child's playing as she's trying exciting, adventurous, and dangerous situations in her fantasy. The easier the way is she's gone through adventures the more happiness she has just...like a playing child...You will be more and more relaxed you have more and more ease to direct your attention to what I am telling you... and to your mind...

Comment: Her hand is getting closer to her face.

T: Good. Your arm is finding the arm of your armchair automatically, and, just let yourself relax and get away from common daily world... Let yourself be... Meanwhile I'm also relaxed. I also begin to get into a special world, into the world of hypnosis. And I just let the same image vivify that is presenting for you. I'll be partly awaken and I'll be partly in your fantasy-world. I'm going to anchor in reality surrendering myself half to your fantasy. We shall see the castle, soon. And we shall see the figures of your fantasy. This is your castle with those wonderful rooms and crystals, with Fairy Helen and the old lady, the man with straw-hat, and the other persons....Tell me if you could see the castle and me in your imagination. What are they like now?

Comment: Double trance technique is attempted to produce tandem hypnosis (Scagnelli, 1980; Vas \& Császár, 2013).

E: Now we enter a garden, a garden full of tulips. We're walking among flowers. You and me.

Comment: Fairy Helen and the other figures are not present except Eve and me. I wonder who is evil, she or me? The castle cannot be seen either, however, there is a garden with flowers. This can be considered as a culmination of her positive transference expressed in symbols (Stolorow, Brandchaft \& Atwood, 1987). The tulip is likely to be the symbol of sexual relations in Hungarian folklore (Antalfai, 2006; Hoppál et Alii, 1988).

$\mathrm{T}$ : There're a lot of nice tulips over there.

E (excitingly): Wonderful tulips! Yellow and red, they're so beautiful!

$\mathrm{T}$ : Yes, I can see.

Comment: My conscious level is of a mild hypnotic trance state. Due to therapeutic splitting I control the whole process with my executing and monitoring Ego functions maintaining reality control for Eve and me, that is, I am undoubtedly anchoring in reality while my experiencing Ego functioning is lent to the patient (Murray-Jobsis, 1988). She can see colorful images, I can see images only in my fantasy. As a matter of fact I would not dare to sink into a deeper level of regression as I would loss my control function.

$\mathrm{E}$ : There're even roses and every kind of tiny little flowers. They're very nice.

$\mathrm{T}$ : Who can be the gardener?

E (passionately): Well, Fairy Helen may be. What a beautiful garden it is! What a nice big, very very big garden! With flowers and flowers all around...There's a nook in this garden...

11 Magical Mystery Tour is the title of one of the Beatles' Albums.

IJTCM: http://escipub.com/international-journal-of-traditional-and-complementary-medicine/ 
T: Really? We should have a look at it! What can be hidden there?

E: I'm afraid of being there. You're urging me to go together (she is tittering).

T: Let's go together. You shouldn't be frightened.

E (gimaces appear on her face while shaking her head).

T (realizing Eve' non-verbal signals): What've you seen?

$E$ (with weeping tone): A devil.

$\mathrm{T}$ (responding immediately with warm tone): Very good! Well, let's have a look at this devil! His ${ }^{12}$ body's shaggy, covered with coarse reddish hair. He's something like this as I can see. He's got horseshoes. And he's putting out of his big and red

$T$ \& $E$ (at the same moment): tongue!

$E$ (with fear): Exactly!

Comment: Previously, when a psychotic or a borderline patient experienced threatening imageries I was anxious very much as well. Later I gave up being anxious realizing that these feelings can be related either to the patient' inner productions or his unconscious tests of my endurance, finally, some symbolic pictures of transference. Therefore I can help to process these threatening emotions in case of accepting attitude.

$\mathrm{T}$ : But I can see him to be funny.

Comment: Instead of defense I suggest a coping strategy to Eve.

$E$ : But l'm afraid of him.

T: This devil should be made gentle. What shall we do with him?

$\mathrm{E}$ : I don't know. He should be given something in order that we couldn' be hurt.

T: OK: What should we give him?

E: I'm going to pick flowers.

T: It'll be good. I'll help you.

12 According to an image in my fantasy the devil seems as a male person.

IJTCM: http://escipub.com/international-journal-of-traditional-and-complementary-medicine/
E: A thorn has hurt my finger.

Comment: It is a symbol of sexual trauma and the first menses.

T: Never mind! That can quite easily happen. I think this flower's got magic power. It must have some impact on the devil.

$\mathrm{E}$ : It must be because we're in Fairy Helen's garden, which's got magic power.

T: Sure. Then...

E (interrupting my talk): Shall we give him the flowers?

T: Yes! And let's see what's happening!

$\mathrm{E}$ (in a childish tone): Please, give it to him, because I don't dare!

T: All right. Well, come on! Strech out your hand, your big shaggy paw! Here you are!...He's taken it...And what can you see now?

$E$ (with a wondering joy): He's smiling! l've never seen such a thing in my life.

$\mathrm{T}$ : His face is slowly turning a bit human.

$\mathrm{E}$ : Indeed. He's pulled his tongue back.

$\mathrm{T}$ : And he doesn't seem to be so grotesque.

Comment: This process is seen to clear inner reality control and to neutralize dangerous inner mental objects in order that libidinal object constancy be established (Fraiberg, 1969).

E: Yes, indeed.

$T$ (in astonishment): Now then! As if he took after somebody.

E (being amazed): Sure.

$\mathrm{T}$ : Does he look familiar?

$\mathrm{E}$ : Yes, he does.

$\mathrm{T}:$ Who is he?

$E$ (after a short while): An uncle of mine.

T: Yes. All right. And now try to imagine that time when this uncle behaved towards you as if he were a devil. We can go back in your life to that time and to that moment. You can easily recollect it. This picture can be vivified nearly of itself. 
Comment: Affect Bridge Technique (Watkins, 1971), which, projecting a present affect into past, finds out a proper event.

$\mathrm{E}$ : He's never hurt me...

Comment: This is not true, because it turns out later that he is the uncle, who daggered his love partner with the knife. Nevertheless, this narrative could not be told in the presence of a videocamera.

E...still takes after him...

$E \& T$ (just at the same time): the devil...

E: But why?

$\mathrm{T}$ : Just let your feeling, your fear of him bring you back to that period of your life when seeing him as if he had been a devil.

E: He's putting his tongue out. It's so ugly!

Comment: Meanwhile my excellent colleague Mr. Ferenc Túry MD, PhD, who assumed the role of the cameraman, is focusing on the microphone in my hand. After the session we could notice a shocking analogy, even synchronicity according to Jung to see the microphone as an outer, and, the tongue as an inner phallic symbol (Jung, 1987). They presented a scene of sexual trauma Eve had probably suffered as a girl.

$\mathrm{T}$ : Yes. But we've already learned how to overcome this diabolic trait...It might have happened to you when you were a little girl. It might've been an unimportant thing that happened to somebody else, and, you could just only see it. Just let an image emerge in your fantasy.

E (after a long pause): My uncle's an alcoholic man and this must be the reason for my seeing him as a devil.

$\mathrm{T}$ : Yes. Just imagine when he behaved in that way.

$\mathrm{E}$ : At such times he could squeeze one's hand so hard that his fingers imprinted in the other's, although, he is a thin and lean man.

$\mathrm{T}$ : Did it happen when he drank alcohol?

E: Yes.
$\mathrm{T}$ : Please, imagine that moment happening now, and you have the possibility to tell him off.

E (angrily): Get out of my sight! I don't want to see him having such a nasty sight! It's so ugly!

$\mathrm{T}$ : What does he look like now?

$\mathrm{E}$ : His tongue is hanging out again, his horns're sharp, his ears look as if they had been made grown (she's tittering) or become longer.

T: They've become distorted by drinking.

E. Yes, indeed.

T: He looks like a drunk.

$E$ (being amazed): Sure, it is.

$\mathrm{T}$ : Well, you're able to get him out of the habit of drinking alcohol.

E (in a childish tone): What could I do with him? With magic flowers?...

$\mathrm{T}$ : Well, that was an efficacious medicine. We can try it again. You might give him a drink for substituting alcohol. Where do you think we can find it?

$\mathrm{E}$ : What if we press fluid out of rose-leaf?

$\mathrm{T}$ : Very good.

Comment: It is evident that her repressed sexual urges, which are distorted by aggressive behavior of her uncle, are represented in the figure of the devil. These sexual urges became pressed from a rose as rose-oil in a symbolic sense now could be given to him.

T: Yes, I can. And I can nearly see that how your uncle's soul and body will be cured.

E: I ask him if I could spread it on his face.

T: OK.

E: He's allowed me to do so. And I'm spreading it on his face. Please, do help me!

T: All right, I help you. He'll be enchanted to be handsome. 
$E$ (in that very moment her face has become beautiful putting on a Mona Lisa-like smile) ${ }^{13}$ : Hmmmm...That shaggy hair begins to be vanishing. His tongue's becoming shorter.

$\mathrm{T}$ : His horns too...

$\mathrm{E}$ : His horns too, indeed.

T: He'll become another man. And he'll never be a devil anymore....Don't you think him to have been the chief of devils?

$\mathrm{E}$ : He could be as he was very similar to that.

$\mathrm{T}$ : Ask him where the rest of the devils are.

$\mathrm{E}$ (in a much deeper voice unconsciously symbolizing hell): He says they're in hell and he's just come up.

T: All right. As I can see he belongs to us standing by our side from this time on. What do you think?

E: You're right. I don't think he could become devil again since this balsam has helped his diabolic form disappear. He's become a man!

T: Sure. That's for him to struggle his own fight against the rest of devils. That's not our business, we're able to make friends with him. I wonder what role he'll play in this castle.

$\mathrm{E}$ : I think he could be a guard or a gardener in this beautiful garden.

T: A gardener. Very good since flowers have helped him.

$\mathrm{E}$ : He can work well among nice flowers.

T: Then, I give him a hoe and a rake. Rank grass'll be raked.

E: OK.

$\mathrm{T}$ : Very good. Then we say good bye to your uncle and the devils for evermore. You'll never meet them. You've got rid of them and they won't ever predict evil prophecies to you. You can see that your own feelings concerning your uncle became evil when you were ill. You have relieved of bulk of evil feelings.... And now we'll return to reality into this room and wake up.

$E$ (opens her eyes).

T: How're you feeling?

E: Thank you, quite well...That devil was so threatening...Finally, everything's turned out well. He was so ugly, indeed, his big tongue hung out as long as his waist, not to speak of his shaggy paws and horseshoes, it isn't good to think about either. And how he's become gentle, it's interesting! (Now she casts a soft glance at me.) Will that thought become gentle in such a way in my mind when I think about them?

$\mathrm{T}$ : What do you think?

$\mathrm{E}$ : Why, it must be gentle once because my fear of them can't be maintained for ever.

$\mathrm{T}$ : The way things're going it'll come true.

E: I'd like it very much.

T: However, it's a long-term fight.

Comment: Meanwhile my enormous fight can be seen on the video as I am pulling at the microphone here and there. It is as if I had missed something, and $I$ felt tense uncomfortably. Later I think of Eve to make the devil's phallic traits disappear, and I became castrated by her act in a symbolic way. At the end of this session I felt so exhausted as an "object in use" according to Winnicott's sense (Winnicott, 1969).

E: I see.

T: It's interesting that you didn't say anything about Fairy Helen, and, I didn't have the image about her either.

E: I couldn't see anything except the devil and the flowers.

T. Could you see me?

E: Yes, I could.

Comment: According to Eve' unconsciousness I was the devil itself. The symbol of devil is of the therapist, and, the symbol of flowers is of Eve'.

$\mathrm{T}:$ In this white coat?

${ }^{13}$ This is a cathartic moment (Nichols \& Zax, 1977)

IJTCM: http://escipub.com/international-journal-of-traditional-and-complementary-medicine/ 
E (smiling): No, without the white coat. With a tie (!)

$\mathrm{T}$ (laughing): With a tie. A tie against exorsism.

Comment: That is an evident slip of the tongue. According to that my tie serves as a tool against exorcism in our common unconscious fantasy. As a matter of fact there was no exorcism in the course of hypnosis, on the contrary it was a suggestion for Eve to accept the devil in a gentle form.

$\mathrm{E}$ : When I dream about you I can see you with a tie. I really don't know what the meaning of the tie is.

$\mathrm{T}$ : You told me you could imagine men well dressed with a tie.

E: Could be.

$\mathrm{T}$ : Can we finish this session, please?

E: OK. Thank you.

The scene in the last, 12th hypnotic session is the garden of fairy castle. Without saying a word we know both of us that Fairy Helen exists no more she has become fused with Eve. To my suggestion Eve is meeting all of her alive and dead relatives including her witchgrandmother from whom she always felt threatening. Threatening is solved by empathy. She makes a formal dinner, all of the guests are invited. Another curious although psychologically predictable fusion has happened: the man with straw-hat, the gardener as the devil earlier and her uncle have become to the same person. Figures of tale have been converted into real people, thus, hypnotic tale can be continued no more. Psychological integration has been established due to our cooperation in therapeutic relationship involved hypnoanalytic process (Fromm, 1984; Kernberg, 1985).Eve, the desperate and anxious person has been gradually better in two weeks.

Follow up: We meet every 5 year, when she looks like a woman with Rabelais-type humor maintaining mental balance.

\section{Epilogue}

Archetypes and symbols of collective unconsciousness could break through ego defense mechanisms to blow acute psychosis when analogous events are happening in objective reality, however, expression of emotions, affects and drives exaggerated by that objective events meet with difficulties because of hypocrise to insist on an illusion at any cost of saying or thinking that „everything is OK" or "nothing has happened". As a little girl Eve could see the grandmother, who personified into a witch but she denied what she looked at completely concealing reality. Omnipotent denial or neglect are also kind of primitive defense as splitting is, which can lead extended psychological blind spots and distorsions in perceptual processes (Suppes \& Warren, 1975). If what she looks at does not exist for her in outer reality that must exist in her inner reality gaining unconscious internal representation by means of introjection. So lack of external reality can be counterpointed with internal fantasy (Ogden, 1982 \& 1986). Thus, the witch and the devil, that is, Evil will be Eve herself from her childhood, consequently (Niederhofer, 2002). This is considered as "Conceptio Maculata", that is, possession by Evil. Sexual roles are likely to have diabolic traits for Eve so starting matrimony favors Evil forces to be emerged. A devil could not be regarded as suitable to be a living person but it is a symbol, which, as we saw, appeared as several figures in Eve'destiny. Blowing psychosis was a consequence of unbearable tense caused by unacceptable diabolic sexuality, the womanhood and the maternal role for Eve (Pedersen, 1991; Vas, 1993 \& 1994).

I think of Eve' torture and healing as not being a process in linear time (Vas, 1993b). Her suffering is likely to be a moment lasting forever closed into presence, which is beyond our digital hemisphere used for rational comprehension and measurement of linear time. Present and past are fused in her 
experiential horizon (Kurtz, 1986; Fink, 1993; Matte-Blanco, 1975). However, present and future are also fused due to evil prophecies are realized (Ward, 1989). This is a cyclic chronological order or a cyclic time dimension: fast return of determinated chain of events, that is, „circulus vitiosus” (Eliade, 1993; Jung, 1992). Eve' soul turns round Lucifer's Earth as a pale Moon. Gravitation of Evil's magma does not allow to break through the ring of that attraction. Nevertheless, Eve' soul is led to higher circuits along a fictitious spiral by means of imagery process of hypnosis_including Fairy Helen's ethereal being (Assagioli, 1969 \& 1993). The highest point is Eve' pregnancy, which is aborted, showing to the depths meaning tragedy. Imagine a spiral Galaxy with a bubbling mass of material as a black hole in the centre, which can be the magma of psychosis, the Evil. A spiral shell encircling Evil may be the world of psychosis: the hermaphrodite, the Centaur and space creatures and evil demons begotten by the former, which beget evil prophecies (Carman \& Carman, 2003). Fairy Helen is a symbol of breaking up and ascension, who fixes firmly maternal axis of Galaxy, along that imagery symbols of hypnosis are in order joined the queue alternately presenting good and bad. Another axes forms several arms of Galaxy: axes of reality-irreality, male- female, goodbad and aggression-libido. Menwhile material carrying energy are getting thin, reality becomes to more bearable, fantasy are getting ethereal, then, aggressive and erotic impulses will be neutralized: from Centaur will be magic chair, later Pegasus, and the devil will be a gardener (Fontana, 1995; Grof, 1975).

That Galaxy is symbolically constructed from psychosis, hypnosis and reality. It is a narrative belongs to Eve' and the therapist's Universe, but in a certain sense it might be a story of Big Bang too, happened again in a deluded mind. As a matter of fact we can see directions, gravitation, ascension and descension, and breaking out of labirinth. Time depicts difficult loops, spirals, turns back or goes round. Time labirinth is of symbols, too. Meanwhile the patient's unconscious fantasy controls emergence of symbols, the patient and the therapist try together to unravel puzzle of symbols in order to find themselves face to face with much more mysterious ones. It is not related to timely events but a comprehensive and emotional process. All of loving acceptance presents everlasting healing to the patient, immediately vanished in the case of the slightest weakness of love and attention. Thus, the symbols of fantasy reflect not only the patient's internal world but the vicissitude of actual intensity of the therapeutic relationship as well.

\section{Biography}

Vas, József Pál MD, ECP, a former president of the Hungarian Association of Hypnosis, supervisor hypnotherapist, Head of Department of Psychotherapy in Miskolc, Hungary, now is retired. He is the author of the book titled Hypnose bei Psychosen, München, Quintessenz, 1993, and two further professional books edited in Hungary. He has recently developed the Dynamic Tandem Hypnotherapy method. He can be contacted by e-mail: vasjozsefpal@gmail.com

Phone: +36 30687 2993, +36 46414544

Address: H-+527. Soltész Nagy Kálmán u. 1. $1 / 5$, Miskolc, Hungary.

\section{References}

1. Antalfai M. A nő személyiségfejlődésének értelmezése a magyar népmesékben (Interpretation of Female Personality's Development in Hungarian Folktales). Pszichoterápia 8(2): 105-118, 1999.

2. Antalfai M. A női lélek útja mítoszokban és mesékben (Female Soul's Way in Myths and Tales). Budapest, Ú.M.K, 2006.

3.

ssagioli R. Symbols of transpersonal experience. Journal of Transpersonal Psychology, 1: 33-45, 1969.

4. Assagioli R. Transpersonal development. Glasgow: Harper Colins, 1993.

5. Berwick $P$ \& Douglas D. Hypnosis, exorcism, and healing: A case report. The American Journal of 
Clinical Hypnosis, 31, 18-27, 1977.

6. Bettelheim B. A mese büvölete és a gyermeki lélek (The uses of enchantment). New York, Knopff, 1976.

7. Brown DP \& Fromm E. Hypnotherapy and Hypnoanalysis. London, Lawrence Erlbaum Ass. Hillsdale N.J.,1986.

8. Carman EM \& Carman NJ. Cosmic cradle. Austin, Sunstar Publ. 2003.

9. Edelstein MC. Trauma, Trance, and Transformation. New York, Brunnel/Mazel, 1981.

10. Eliade M. Az örök visszatérés mítosza (Myth of Eternal Returning). Budapest, Európa, 1993.

11. Ferenczi S. Trauma in Psychoanalysis. In Psychological Problems Reflected in Psychanalysis. pp. 439-452, ed. by A. Linczényi. Budapest, Magvető, 1933/1992.

12. Fink K. The bi-logic perception of time. The Journal of Psycho-Analysis 74: 303-312, 1993.

13. Fontana D. A szimbólumok titkos világa (Secret World of Symbols). Budapest, Tericum, 1995.

14. Fraiberg S. Libidinal Object Constancy and Mental Representation. Psychoanalytical Study of the Child 24, 1, 9-47, 1969.

15. Franz M-Lv. Nói mesealakok (Female Figures In Tales). Budapest, Európa, 1992.

16. Freud S. Three essays on the theory of sexuality. The Standard Edition of the Complete Psychological Works 7, pp. 125-245, London, Hogarth Press, 1905/1953.

17. Friedenthal R. Goethe élete és kora (Goethe, His Life and His Era). Budapest, Európa, 1978.

18. Friedman, $N$ \& Lavander J. On receiving the patient's transference: The symbolizing and desymbolizing countertransference. Journal of American Psychoanalytic Association 45, 79103, 1997.

19. Fromm E. Hypnoanalysis - with Particular Emphasis on the Borderline Patient. Psychoanalytical Psychology 1(1), 61-76, 1984.

20. Gabbard GO. Psychodynamic psychiatry in clinical practice. Washington DC, American Psychiatric Press, 1994.

21. Gill MM \& Brenman M. Hypnosis and related states. Psychoanalytical Studies in Regression. New York, International Universities Press, 1959.

22. Grof S. Realms of the human unconscious. New York, Viking, 1975.

23. Hart Ovd. Rituals in psychotherapy. New York: Irvington Publishers, 1983.

24. Herman J. Trauma és gyógyulás (Trauma and Healing). Budapest, 2003, Háttér Kiadó.

25. Hilgard ER. Divided Consciousness. New York, John Wiley \& Sons, 1986.

26. Hilgard J. Imaginative involvement: Some characteristics of the highly hypnotizable and nonhypnotizable. International Journal of Clinical and Experimental Hypnosis 22, 138-156, 1974.

27. Hoppál M, Jankovics M, Nagy A \& Szemadám G. Jelképtár (Collection of Symbols). Budapest, Helikon, 1990.

28. Jilek WG. Indian Healing. Surrey B.C. Canada, Hancock House, 1988.

29. Jung CG. On the nature of the psyche. Princeton, Bollinger Series, 1973a.

30. Jung CG. Four archetypes. Princeton, Bollinger Series, 1973b.

31. Jung CG. Man and his Symbols. London, Pan Books, 1978.

32. Jung CG. Selected Writings, pp. 65-86, ed. by A. Storr. London, Fontana Press, 1983.

33. Jung CG. Synchronicity - an acausal connecting principle. London, Ark, 1987.

34. Jung CG. Response to Job's Book. Budapest, Akadémia, 1992.

35. Jung CG. Sysygia: Anima and Animus. In Aión, pp.17-27, ed. by CG. Jung. Budapest, Akadémia, 1993.

36. Kernberg OF. Borderline Conditions and Pathological Narcissism. New York, Jason Aronson, 1985.

37. Kohut H. The Restoration of the Self. New York, International Universities Press, 1977.

38. Krippner S. Cross-cultural perspectives on hypnotic-like procedures used by native healing practitioners, pp. 691-717, in JW. Rhue, SJ. Lynn \& I. Kirsch (Eds.). Handbook of Clinical Hypnosis. Washington, DC, American Psychological Association, 1993.

39. Kurtz SA. Psychoanalysis of time. Journal of American Psychoanalytic Association, 36, 9851004, 1986.

40. Laufer ME. Body image, sexuality and the psychotic core. The International Journal of Psychoanalysis, 72, 63-71, 1991.

41. Levin K. Unconscious fantasy in psychotherapy. American Journal of Psychotherapy, 50(2), 137153, 1996.

42. Masterson JF \& Rinsley DB. The borderline syndrome: the role of the mother in the genesis and psychic structure of the borderline personality. Internationa Journal of Psychoanalysis 56, 163-177, 1975.

43. Matte-Blanco I. The unconscious as infinite sets. London, Duckworth, 1975.

44. Merkur D. The Nature of the Hypnotic State: A Psychoanalytic Approach. International Review of Psycho-Analysis 11, 345-354, 1984.

45. Murray-Jobsis J. Hypnosis as a Function of Adaptive Regression and of Transference. American Journal of Clinical Hypnosis 30(4), 241-247, 1988.

IJTCM: http://escipub.com/international-journal-of-traditional-and-complementary-medicine/ 
46. Nichols MP \& Zax M. Catharsis in psychotherapy. New York, Gardner, 1977.

47. Niederhofer $H$. Children who are victims of violent conflicts often forget the principles of stable attachment and confidence, pp. 81-82, in Janus L. (Ed.). The significance of the earliest phases of childhood for later life and for society. Heidelberg, ISPPM, 2002.

48. Ogden TH. Projective identification and psychotherapeutic technique. New York, Jason Aronson, 1982.

49. Ogden TH. The Matrix of the Mind. New York, Jason Aronson, 1986.

50. Pattison EM, Kahan J \& Hurd GS. Trance and Possession States. In Handbook of Altered States of Consciousness, pp. 286-310, ed. by BB. Wolmann \& M. Ullman New York, Van Nostrand Reinhold Company, 1986.

51. Pedersen LE. Dark Hearts. The Unconscious Forces That Shape Men's Lives. Boston, Shambala, 1991.

52. Pisztora F \& Kunt E. Delusions of Influence Related to Superstitious Believes in Hungary of Monarchic Period, pp. 332-341, in Belief Systems and Social Mind. Eds. by T. Frank \& M. Hoppál. Budapest. Tömegkommunikációs KK, 1980.

53. Safranski R. A Gonosz avagy a szabadság drámája (Das Böse oder das Drama der Freiheit). München-Wien, Carl Hanser Verlag, 1997.

54. Sarbin TR \& Coe WC. Hypnosis - A Social Psychological Analysis of Influence Communication. New York, Holt, Rinehart \& Winston, 1972.

55. Scagnelli J. Hypnotherapy with Psychotic and Borderline Patients. The Use of Trance by Patient and Therapist. American Journal of Clinical Hypnosis 22(3), 164-169, 1980.

56. Schram F. Boszorkányüldözések Magyarországon III. (Witch Trials in Hungary III.) Budapest, Akadémia, 1982.

57. Spanos NP. Hypnosis, Demonic Possession, and Multiple Personality. In Altered States of Consciousness and Mental Health, pp. 96-124, ed. by CA. Ward, London, Sage Publications, 1989.

58. Stolorow RD, Brandchaft B \& Atwood GE. Psychoanalytic technique: An intersubjective approach. Hillsdale, N. J., The Analytic Press, 1987.

59. Suppes $P$ \& Warren $H$. On the generation and classification of defence mechanisms. International Journal of Psychoanalysis, 56, 405414, 1975.

60. Szimonidesz L. Primitív és kulturális vallások
(Primitive and Cultural Religions). Budapest, Dante, 1931.

61. Szondi L. Káin a törvényszegő, Mózes a törványalkotó (Cain against the law, Moses making the law). Budapest, Gondolat, 1987.

62. Vas J. Hypnose bei Psychosen. Berlin-München, Quintessenz Verlags-Gmbh, 1993.

63. Vas J. Hypnose, Psychose und Realität: Die Transformation psychotischer Symbole in Verlaufe des Heilungsprocesses. Experimentelle und klinische Hypnose, X (1), 35-49, 1994a.

64. Vas J. A megosztott idő. Néháy gondolat a megosztott tudat idődimenzióiról (Divided Time. Some Thoughts upon Time-Dimensions of Divided Mind). Magyar Pszichológiai Szemle, 50(3-4), 189-215, 1994b.

65. Vas JP \& Császár N. Tandem Hypnotherapy. International Body Psychotherapy Journal 12(1), 74-86, 2013.

66. Vámosi NI. Merlin, a bárd és Wagner, a zeneszerző (Merlin the Bard, and Wagner the Composer). Budapest, Private Edition,1985.

67. Ward CA. Possession and Exorcism. In Altered States of Consciousness and Mental Health, pp.125-144, ed. by CA. Ward, London, Sage Publications, 1989.

68. Watkins J. The Affect Bridge: A Hypnoanalytic Technique. International Journal of Clinical and Experimental Hypnosis 19, 21-27, 1971.

69. Watkins JG \& Watkins HH. Hypnosis, Multiple Personality, and Ego States as Altered States of Consciousness, pp. 133-158, in Handbook of States of Consciousness, ed. by BB. Wolmann \& M. Ullman, New York, Van Nostrand Reinhold Company, 1986.

70. Weitzenhoffer AM \& Hilgard ER. Stanford Hypnotic Susceptibility Scales: Forms $A$ and $B$. Palo Alto, Canada, Consulting Psychologists Press, 1959.

71. Winnicott DW. The use of an object. The International Journal of Psychoanalysis 50, 711716, 1969.

72. Young-Eisendrath $\mathrm{P}$ \& Wiedemann F. Female authority. New York, Guilford, 1987.

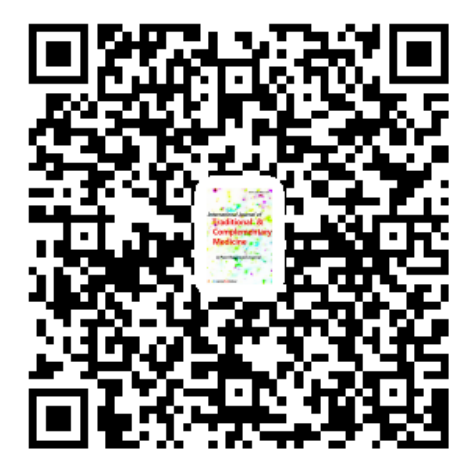

IJTCM: http://escipub.com/international-journal-of-traditional-and-complementary-medicine/ 